\title{
Household Waste Management; Voices of Residents of Anaocha Local Government Area of Anambra State, Nigeria
}

\author{
E. C. Azuike ${ }^{1,2^{*}}$, S. A. Nwabueze ${ }^{1}$, P. E. Onyemachi ${ }^{3}$, B. N. Egenti ${ }^{4}$, K. C. Okafor ${ }^{5}$, \\ R. C. Aniemena1,2, I. N. Udedibia ${ }^{1,2}$, J. O. Nwodo ${ }^{6}$ \\ ${ }^{1}$ Department of Community Medicine, Nnamdi Azikiwe University Teaching Hospital, Nnewi, Nigeria \\ ${ }^{2}$ Foundation for Health and Development in Nigeria \\ ${ }^{3}$ Department of Community Medicine, Abia State University, Aba, Nigeria \\ ${ }^{4}$ Department of Community Medicine, University of Abuja, Abuja, Nigeria \\ ${ }^{5}$ Department of Public Health, Federal Medical Centre, Keffi, Nigeria \\ ${ }^{6}$ Faculty of Medicine, Nnamdi Azikiwe University, Awka, Nigeria \\ Email: :emmanazuike@yahoo.com
}

Received 18 November 2015; accepted 18 December 2015; published 22 December 2015

Copyright (C) 2015 by authors and Scientific Research Publishing Inc.

This work is licensed under the Creative Commons Attribution International License (CC BY).

http://creativecommons.org/licenses/by/4.0/

(c) (i) 0pen Access

\begin{abstract}
Background: Waste management is the generation, prevention, characterization, monitoring, treatment, handling, reuse and residual disposition of social waste. The various methods of waste disposal include: recycling, composting, barging, burying, landfills method, incineration, and the use of mechanical destructors. Objective: The aim of this study was to assess the knowledge, attitude and practice of house hold waste management among the respondents and the factors affecting their choice of method. Methodology: This was a cross sectional descriptive study. There were 270 respondents. The study was carried out among households in Anaocha LGA of Anambra state. The study made use of a semi-structured interviewer administered questionnaire. Result: Majority had good knowledge of waste management and portrayed good attitude towards waste management practices. The commonest method of waste disposal practiced by the community was burning and majority practiced the various methods because the methods were convenient for them. Conclusion: The study showed that people, despite having good knowledge and attitude towards waste management still practiced wrong methods.
\end{abstract}

\section{Keywords}

Household Waste, Management

\footnotetext{
${ }^{*}$ Corresponding author.
}

How to cite this paper: Azuike, E.C., Nwabueze, S.A., Onyemachi, P.E., Egenti, B.N., Okafor, K.C., Aniemena, R.C., Udedibia, I.N. and Nwodo, J.O. (2015) Household Waste Management; Voices of Residents of Anaocha Local Government Area of Anambra State, Nigeria. Journal of Environmental Protection, 6, 1394-1401. http://dx.doi.org/10.4236/jep.2015.612121 


\section{Introduction}

Waste is a term used for unwanted materials. These are substances or objects which are disposed of, or are intended to be disposed of, or are required to be disposed of, by the provision of national law [1]. Wastes are materials that are not prime products (that is, products produced for the market) for which the initial users have no further use in terms of his/her own purposes of production, transformation or consumption and of which he/she wants to dispose [2]. From the foregoing one can say that waste includes physical things that are of no use to the human beings who are in the immediate environment where such physical things are located. The human beings may or may not be the original owners of the physical things. The physical things in question may or may not have been previously useful to the human beings in its present environment. Waste management is the generation, prevention, characterization, monitoring, treatment, handling, reuse and residual disposition of social waste [3]. The steps in waste management include waste generation, waste storage, waste collection and waste disposal. This explanation actually means that waste management starts from the very point in time the item ceases to be useful to the human being in its immediate environment. Household waste generation is closely linked to population, urbanization and affluence. This is because the more the human beings are, the more the items that they will no longer deem useful are. Disposal of waste is considered one of the main problems faced in the world today and so, it is very important to know the different ways of disposing the waste materials produced in the home. The choice of method of disposal depends on such factors like: the physical characteristics of the place, the quantity and quality of the waste to be disposed and the cost and the culture of the community. The various methods of waste disposal include landfills method/controlled tipping, incinerations, recycling, composting, barging, use of mechanical destructor, indiscriminate open dumping and burying.

A study done in Somalia to assess the knowledge, attitude and practice of solid waste disposal management shows that $32 \%$ burn the garbage somewhere near the house, that $27 \%$ dump garbage outside their house, that $27 \%$ bury garbage somewhere near the house, that $4 \%$ hail it to the community dump (illegal collection point), that $1 \%$ dump it in a secluded spot away from the community, that $3 \%$ collect it and take to the landfill and that $0 \%$ recycle cans or other waste [4]. This is not surprising because Somalia is a developing country. Most developing countries are known to lack modern household waste management systems because of the paucity of funds and backwardness in level of technology. Another study done in South Africa reported that 80\% of the community members had the knowledge about waste management [5]. A study done by Mukui S. J. in Kenya showed that only $26.2 \%$ of households in the study area practiced correct solid waste management. When asked if they had ever heard of segregation of solid wastes, $60 \%$ of households said they had heard of it [6]. In Abeokuta, Nigeria it was reported that $4.74 \%$ of the respondents which constituted a majority, burn their waste, $26.28 \%$ make use of open dumping method, $14.17 \%$ employ the cart-pushers, $6.28 \%$ bury theirs while the remaining $5.81 \%$ use the local government truck. It was also found out that $42.78 \%$ of the respondents threw their waste indiscriminately in near-by bushes, 33.5\%, $13.66 \%$ and $10.05 \%$ into gutters, nearby houses and into the river respectively [6].

In Ibadan, Nigeria a study revealed that among secondary school students open burning (78.6\%) is the commonest method of waste disposal [7]. Another study done in Ado-Ekiti reported that about 96.7\% of the respondents were not aware of any house hold recycling activities while only $3.3 \%$ were aware, out of which only $15.4 \%$ claimed that they recycled their house hold solid waste. Only about $0.8 \%$ of respondents made compost of their wastes, 6.9\% separate news papers, books, plastics, bottles from other house hold waste for recycling [8]. A study done by Suleiman in Katsina state showed that $27 \%$ of house hold waste were appropriately disposed inside the refuse collection facility such as refuse collection centre bin containers. Open space accounted for about $30 \%$ of waste disposed which was done inappropriately. Uncompleted building and structure and water pond accounted for about $13 \%$ each mainly in the city and residential layout. Dumping of refuse by the road side was $10 \%$ which was mainly in the inaccessible parts of the metropolis such as Sajai, Masanawa, Kijar Yandawa. Five per cent of waste was dumped into gutter (drainage) which caused flooding. Burning of waste accounted for about 30\% while composting accounted for about 20\% [9]. A study aimed at examining the waste handling practices among households in Awka, an urban area in South Eastern Nigeria showed that 85\% of the households stored their waste in a closed container outside the house, $73 \%$ disposed of their waste through the inefficient government waste management agency, 27\% dumped theirs in unauthorized areas and the remainder patronized private mobile cart-pushers. Majority of the respondents (87.5\%) did not sort their waste prior to disposal. Despite very good knowledge of waste recycling (95\%), only 17.5\% practiced it [10]. The aim of this study was to assess the knowledge, attitude and practice of household waste management and the factors influencing their choice of method in Anaocha LGA of Anambra state. 


\section{Methodology}

The study was carried out in Anaocha Local Government Area. Anaocha local government area is one of the twenty one Local Government Areas that make up the present Anambra State, Nigeria. It is a rural Local Government Area with its headquarter at Neni [11]. Anaocha spans over 171.62 kilometres with a population of 284,215 based on the 2006 Census [12]. The major occupation of the people of Anaocha is farming, followed by trading and civil service.

Study Population: The study population comprised Heads of Households living in Anaocha LGA.

Study Design: This was a descriptive cross sectional survey of household waste management in Anaocha.

Sample size determination: Was calculated using the formula for calculation of sample size for cross sectional studies [13]:

$$
n=\frac{z^{2} p q}{d^{2}}
$$

where $n=$ Minimum sample size.

$z=$ Standard normal deviation (1.96).

$p=$ Prevalence in project area (0.95 used for sample size needed) [10].

$q=1-\mathrm{p}$.

$=1-0.95=0.05$.

$\mathrm{d}=$ Degree of accuracy $=0.05$ (a constant).

Thus

$$
\begin{aligned}
& n=\frac{1.96 \times 1.96 \times 0.95 \times 0.05}{\left(0.05^{2}\right)} \\
& n=\frac{0.1825}{0.0025} \\
& n=73
\end{aligned}
$$

Anticipated attrition was taken as $10 \%$ of $72.99=7.3$.

Therefore, minimum sample size was $72.99+7.3=80$.

However in order to increase the power of the study, 270 households were studied.

Sampling technique: Multi stage sampling technique was used. Stage 1: The LGA was divided into clusters then a cluster was selected by simple random sampling. Stage 2: Simple random sampling was used to select 270 households from the cluster to visit, using the pre-existing household numbering.

Inclusion criteria: All households who gave their consent.

Exclusion Criteria: All households who refused to give their consent.

Data collection tool: The measuring tool was a semi-structured questionnaire based on the specific objectives of the study. It was interviewer administered. The questionnaire has 5 sections: section A is on socio-demographic characteristics of the respondents. Section B is on the knowledge of the respondents regarding household waste management. Section $C$ is on the attitude of the respondents to household waste management. Section $\mathrm{D}$ is on the practice of the respondents of household waste management. Section $\mathrm{E}$ is on the factors affecting the choice of disposal practiced by the respondents.

Data analysis: The data collected was entered into, and analyzed using SPSS Version 20. The results were presented in tables and charts.

Ethical consideration: Ethical approval was obtained from the Nnamdi Azikiwe University Teaching Hospital Ethical Committee. Permission was also obtained from the Local Government Area Chairman, the traditional ruler of the town. Consent was also obtained from the various household heads before administering the questionnaire.

Limitations of the Study: This study was conducted in only one Local Government Area in Anambra state because of lack of resources. It would have been better to sample many Local Government Areas in order to get a broader picture of the situation in the state. Also we would have loved to measure the quantities of waste produced by the different households but it was not feasible because of lack of equipments. 


\section{Results}

Table 1 shows the sociodemographic distribution of the respondents. Table 1 shows that the commonest age group was the 40 - 50 years age group. Among the respondents there were more females $(87.4 \%)$ than males (12.6\%). All the respondents were Christians (100.0\%). Among the respondents, the commonest educational level was secondary school (55.2\%), followed by primary education (21.1\%), then nil education (12.2) and tertiary education (11.5\%). Eighty eight point nine percent of the respondents were married, while only $11.1 \%$ were single. The commonest occupation was trading (66.7\%), followed by farming (13.3\%), then civil service (10.0\%), and others (8.9\%).

Table 2 shows the different sources of knowledge of waste management for the respondents. The commonest source of knowledge was family and friends (38.8\%), followed by market place (27.8\%), then newspapers (25.6\%) and electronic media (7.8\%).

\section{Table 1. Socio-demographic distribution.}

\begin{tabular}{|c|c|c|c|}
\hline & Variables & Frequency & Percentage (\%) \\
\hline \multirow{6}{*}{ Age (years) } & $<20$ & 9 & 3.3 \\
\hline & $20-30$ & 58 & 21.5 \\
\hline & $30-40$ & 72 & 26.7 \\
\hline & $40-50$ & 74 & 27.4 \\
\hline & $>50$ & 57 & 21.1 \\
\hline & Total & 270 & 100 \\
\hline \multirow{3}{*}{ Sex } & Males & 34 & 12.6 \\
\hline & Females & 236 & 87.4 \\
\hline & Total & 270 & 100 \\
\hline \multirow{3}{*}{ Religion } & Christianity & 270 & 100 \\
\hline & Muslim & 0 & 0 \\
\hline & Total & 270 & 100 \\
\hline \multirow{5}{*}{ Highest educational level } & None & 33 & 12.2 \\
\hline & Primary & 57 & 21.1 \\
\hline & Secondary & 149 & 55.2 \\
\hline & Tertiary & 31 & 11.5 \\
\hline & Total & 270 & 100 \\
\hline \multirow{3}{*}{ Marital status } & Married & 240 & 88.9 \\
\hline & Single & 30 & 11.1 \\
\hline & Total & 270 & 100 \\
\hline \multirow{6}{*}{ Occupation } & Civil service & 27 & 10.0 \\
\hline & Engineer & 3 & 1.1 \\
\hline & Farmers & 36 & 13.3 \\
\hline & Traders & 180 & 66.7 \\
\hline & Others & 24 & 8.9 \\
\hline & Total & 270 & 100 \\
\hline
\end{tabular}


Table 3 shows the knowledge of the respondents regarding methods of waste disposal. Table 3 shows that the most commonly known method of refuse disposal was open burning (77.8\%), followed by burying (68.1\%), then open dumping (65.2\%), animal feeding (51.1\%) and reuse/recycling (46.7\%).

Table 4 shows the respondents' attitude towards waste around their homes. Majority of the respondents (50.7\%) were "very worried" about waste around their homes. Thirty eight point nine percent of the respondents were "worried" about waste around their homes. Eight point one percent of the respondents were "not worried" about waste around their homes. And only $2.3 \%$ were "not sure" of their attitude towards waste around their homes.

Table 2. Source of knowledge of waste management.

\begin{tabular}{ccc}
\hline Means & Frequency & Percentage (\%) \\
\hline Electronic media & 21 & 7.8 \\
Newspapers & 69 & 25.6 \\
Family/Friends & 105 & 38.8 \\
Market place & 75 & 27.8 \\
Total & 270 & 100 \\
\hline
\end{tabular}

Table 3. Respondents' knowledge of methods of waste management.

\begin{tabular}{ccc}
\hline Methods & Number of respondents & Percentage (\%) \\
\hline Open dumping & Yes 176 & 34.8 \\
& No 94 & 100 \\
Burying & Total 270 & 68.1 \\
& Yes 184 & 31.9 \\
& No 86 & 100 \\
Open burning & Total 270 & 77.8 \\
& Yes 210 & 22.2 \\
& No 60 & 100 \\
Animal feeding & Total 270 & 51.1 \\
& Yes 138 & 48.9 \\
& No 132 & 100 \\
Reuse/Recycling & Total 270 & 46.7 \\
& Yes 126 & 53.3 \\
\hline
\end{tabular}

Table 4. Respondents' attitude towards waste around their homes.

\begin{tabular}{ccc}
\hline Attitude & Frequency & Percentage (\%) \\
\hline Very worried & 137 & 50.7 \\
Worried & 105 & 38.9 \\
Not worried & 22 & 8.1 \\
Not sure & 6 & 2.3 \\
Total & 270 & 100 \\
\hline
\end{tabular}


Table 5 shows respondents' attitude towards the ways other households dispose of their waste. Majority (78.1\%) were "not satisfied" with the ways others dispose of their waste, followed by those who were "satisfied" (11.9\%), then the "very satisfied" (5.2\%) and those that were "not sure" (4.8\%).

Table 6 shows respondents' practice of the monthly sanitation program. The table shows that $93.3 \%$ of the respondents participate in the monthly sanitation program, while $6.7 \%$ replied "no," showing good attitude towards waste management.

Table 7 shows the respondents' method of refuse disposal. Majority of the respondents burn their household wastes (94.1\%). Seventy four point one percent of the respondents practice open dumping. Fifty one percent of the respondents throw their household waste into the bush. Among the respondents, 32.2\% practice composting, while $5.6 \%$ throw their waste into gullies.

Table 8 shows the factors that influence the choice of waste disposal practiced by the respondents. Majority (53.3\%) made a choice of refuse disposal method based on convenience, 38.9\% practice methods because it is common in their locality, while $32.2 \%$ practice methods because it helps them in farming.

\section{Discussion}

In this study, a majority (98.2\%) of the respondents were aware of waste management and the commonest source of knowledge (38.8\%) was family and friends. This is similar to the findings of Moshoette S. G., et al. in a rural community in South Africa where they reported that majority (80\%) of the community members had the knowledge about waste management [5]. The finding that the commonest source of knowledge was family and friends was understandable because the study area was a rural area. In rural areas, there are close knit family relationships and family values are considered sacred unlike in urban areas. Also access to modern methods of information dissemination is reduced unlike in urban areas.

In this study, $50.7 \%$ of the respondents were very worried about waste around their homes, and $78.1 \%$ were not satisfied with the ways others dispose of their waste. Similarly it was reported in Somalia that $69 \%$ of the respondents were not satisfied with the cleanliness of the streets [4]. This finding shows that the respondents desire clean environments and have a good attitude towards proper waste disposal. In this study majority (94.1\%) of the respondents burn their household wastes. This correlates with the findings of Achi H. A., et al. at Abeokuta, Nigeria where majority of the respondents burn their waste [6]. This practice of burning of refuse is common because this is a rural area in a developing country where modern household waste management systems are not available. This disagreed with the findings of a study done in UK which showed that majority of the solid wastes generated in the UK ended in Landfills and recycling also increased dramatically over a period of 9 years (2001 to 2010) [1]. This is understandable because UK is a developed country where modern household waste management systems are readily available. This study showed that majority (53.3\%) of the respondents choose the

Table 5. Respondents' attitude towards the ways other households dispose of their waste.

\begin{tabular}{ccc}
\hline Attitude & Frequency & Percentage (\%) \\
\hline Very satisfied & 14 & 5.2 \\
Satisfied & 32 & 11.9 \\
Not satisfied & 211 & 78.1 \\
Not sure & 13 & 4.8 \\
Total & 270 & 100 \\
\hline
\end{tabular}

Table 6. Respondents' practice of the monthly sanitation program.

\begin{tabular}{ccc}
\hline Do you participate in the monthly sanitation program? & Number of respondents & Percentage (\%) \\
\hline Yes & 252 & 18 \\
No & 270 & 6.3 \\
Total & 100 \\
\hline
\end{tabular}


Table 7. Respondents' methods of waste disposal.

\begin{tabular}{|c|c|c|}
\hline Methods & Number of respondents & Percentage (\%) \\
\hline \multirow{3}{*}{ Open dumping } & Yes 200 & 74.1 \\
\hline & N0 70 & 25.9 \\
\hline & Total 270 & 100 \\
\hline \multirow{3}{*}{ Burning } & Yes 254 & 94.1 \\
\hline & No 16 & 5.9 \\
\hline & Total 270 & 100 \\
\hline \multirow{3}{*}{ Composting } & Yes 87 & 32.2 \\
\hline & No 183 & 67.8 \\
\hline & Total 270 & 100 \\
\hline \multirow{3}{*}{ Reuse/recycling } & Yes 70 & 25.9 \\
\hline & No 200 & 74.1 \\
\hline & Total 270 & 100 \\
\hline \multirow{3}{*}{ Into gullies } & Yes 15 & 5.6 \\
\hline & No 255 & 94.4 \\
\hline & Total 270 & 100 \\
\hline \multirow{3}{*}{ Into waterways } & Yes 12 & 4.4 \\
\hline & No 258 & 95.6 \\
\hline & Total 270 & 100 \\
\hline \multirow{3}{*}{ Into bushes } & Yes 139 & 51.5 \\
\hline & No 131 & 48.5 \\
\hline & Total 270 & 100 \\
\hline
\end{tabular}

\section{Table 8. The factors that influenced their choice.}

\begin{tabular}{ccc}
\hline Factors & Number of respondents & Percentage (\%) \\
\hline It is convenient for me & 144 & 53.3 \\
It is the method practiced here & 105 & 38.9 \\
Feel comfortable with the method & 75 & 27.8 \\
Helps me in my farm work & 87 & 32.2 \\
\hline
\end{tabular}

methods they practice because it is convenient for them. A similar study done by Babayemi J. O., et al. noted that educational status, age, gender and cost of waste collection services were some of the factors affecting solid waste management in Abeokuta [14].

\section{Conclusions}

In conclusion, this study shows that despite having good knowledge of household waste management, the respondents still practice methods that are harmful to the health of the people in the community and the environment. 
We therefore recommend as follows: There is still a need for health education of masses in the rural areas on the dangers of improper waste management. Government should also provide facilities for modern and sustainable household waste management in the rural areas.

\section{References}

[1] The Basel Convention (2015) Text of the Basel Convention. http://www.basel.int/theconvention/overview/textoftheconvention/tabid/1275/default.aspx

[2] United Nations (1996) Glossary of Environment Statistics. United Nations Publications, New York City, 76. http://unstats.un.org/unsd/publication/SeriesF/SeriesF_67E.pdf

[3] Wikipedia (2015) Waste Management. https://en.wikipedia.org/wiki/Waste_management. accessed 20th July 2015

[4] Nwaura, P., Owillah, E.O. and Muhamed, D. (2012) Knowledge, Attitude and Practice Survey on Solid Waste Management. For Humanitarian Initiative Just Relief Aid (HIJRA), Mogadishu.

[5] Moshoette, S.G. and Oladele, O.I. (2013) Assessment of Waste Management Service delivery by Employees and Communities of Ngaka Modiri Molema District Municipality. Journal of Human Ecology, 44, 171-182.

[6] Achi, H.A., Adeofun, C.O., Gbadebo, A.M., Ufoegbune, G.C. and Oyedepo, J. (2012) An Assessment of Solid Waste Management Practices in Abeokuta, South West Nigeria. Journal of Biological and Chemical Research, 29, 177-188.

[7] Adeolu, A.T., Enese, D.O. and Adeolu, M.O. (2014) Assessment of Knowledge, Attitude and Practice of Waste Management in Secondary School in Oyo. Journal of Research in Environmental Science and Toxicology, 3, 66-73.

[8] Momoh, J.J. and Oladebeye, D.H. (2010) Assessment of Awareness, Attitude and Willingness of People to Participate in Household Solid Waste Recycling Programme in Ado-Ekiti, Nigeria. Journal of Applied Science in Environmental Sanitation, 5, 93-105.

[9] Onwughara, I.N., Nnorom, I.C. and Kanno, O.C. (2010) Issues of Roadside Disposal Habit of Municipal Solid Waste: Environmental Impacts and Implementation of Sound Mgt Practices in Developing Country Nigeria. International Journal of Environmental Science and Technology, 1, 409-418.

[10] Modebe, I.A., Onyeonoro, U.U., Ezeama, N.N., Ogbuagu, I.N. and Agam, N.E. (2009) Public Health Implication of Household Solid Waste Management in Awka South East Nigeria. The Internet Journal of Public Health, 1, 7.

[11] Anaocha LGA Official Website (2015). www.anaocha.gov.org.lavingtonhillhouse.com

[12] National Population Commission, Official Website (2015). www.population.gov.ng

[13] Araoye, M.O. (2004) Research Methodology with Statistics for Health and Social Sciences. 1st Edition, Nathadex Publishers, Ilorin, 115-129.

[14] Babayemi, J.O. and Dauda, K.T. (2009) Evaluation of Solid Waste Generation, Categories and Disposal Options in Developing Countries. A Case Study of Nigeria. Journal of Applied Science and Environmental Management, 13, 8388. 